\title{
THE INTEGRATION OF TURKEY IN THE EUROPEAN COMMUNITY AS A STABILIZING FACTOR FOR THE MIDDLE EAST*
}

\author{
Prof. Dr. Alfred TOVIAS**
}

\section{INTRODUCTION}

The purpose of my paper is to evaluate the economic and political effects of a possible accession of Turkey into the EC on political and economic stability in the Middle East.

The main objectives of the European Community nowadays are completing its internal market by the end of 1992 and preparing the ground for monetary union towards the end of this decade. In spite of the EC's desire not to be distracted with other agendas, several countries have already applied for membership (Turkey, Matta, Cyprus, Sweden, Austria and Switzerland) and some other EFTA countries intend to do so as well. Given the economic and political importance of some of the new candidates, the EC has not been able to postpone discussion of the enlargement issue, as witnessed by the contents of the agenda at the European Council of Lisbon last June. In fact the EC will have to take most of these requests into consideration in the near future and I will argue that it is in the Community's interest to deal with the Turkish dossier from now on.

Turkey's membership into the EC certainly requires a prior solution to several economic and political issues. The basic problem is the tense relations between Turkey and Greece over the Cyprus dispute. Greece can block Turkey's accession to the Community and a solution to the conflict is not in sight, at least in the short run, although there has been some minor progress lately. In some sense the end of the Cold War facilitates relations between Turkey and Greece and therefore between Turkey and the EC.

The accessions of Sweden, Austria and Switzerland are likely to be smoother

- Paper presented at the Inaugural Pan-European Conference of the Standing Group on International Relations of the European Consortium of Political Research, 16-20 Seplember 1992, Heidelberg, Germany.

** Professor at the Hebrew University, israel

1 I wish to thank Eyal Inbar for his assistance in the collection of data. 
and faster. Actually, there is a preliminary decision whereby the Commission shall start negotiations with those countries early next year.

Nevertheless, my paper focuses on the possibility of a future southern enlargement of the EC, for at least two reasons: Turkey is probably the most important nonmember Mediterranean country for the EC, both economically and politically. Second, its entry into the Community may have more implications for the Middle East, our focus of interest in this panel, than membership of Central or Northern European countries.

The relations between Turkey and the EC have suffered from sharp fluctuations, thus affecting inevitably the level of cooperation between both partners. It is difficult to discern a trend in those relations looking at the past. The non fulfillment by both sides and at different periods of what had been agreed explains also the prolongation of the time schedules which were foreseen in the different agreements concluded, although more recently the two parties have been trying to catch-up the time previously lost.

This is not the place to review the history of Turkey-EC relations. Suffice it to say that the 1963 Association Agreement contemplated the creation of a Customs Union as well as a Common Market for production factors ("the four freedoms") after a preparatory period of at least five years, after which and upon a decision of the Association Council, the parties would initiate a transitory period of at most 12 years (with some exceptions). The idea was that in practice Turkey would be part of the Common Market (not necessarily of the EC) by the mid-1980s. This timing was not respected. In February 1990 however, and as a result of some improvement in ECTurkey relations since the mid-1980s, the European Council adopted a recommendation by the Commission to establish the Customs Union by 1995. In spite of other precedents, I have assumed for the purposes of this paper that this time the schedule will be respected. Observe that all this does not necessarily mean that Turkey will be accepted as a full member of the EC later on, but there are several factors that the Community will have to take into consideration should it decide to reject EC membership for Turkey upon completion of the Customs Union in the mid-1990s.

First, at that time the applications for accession of rich and developed countries such as Sweden, Austria and Switzerland will have already been considered by the EC. Maybe these last three countries will already be EC members, thus strengthening the industrial base of the EC and the power of Northern countries in it. The extent of restructuring and adjustment aid to these countries will be far smaller than the aid which would have to be allocated to East European countries and Turkey in order 
to bring their economies to the Community level. If so, and provided that Turkey maintains its fast economic development (i.e. a 5.5\% GNP real growth rate for the period 1980-90 according to World Bank figures), it is likely that the hesitations of the EC to membership will lessen. More generally, it may not be easy for the Community to enlarge further the EC without accepting Turkey as well. The EC will not be able to ignore the fact that Turkey is a growing export market for her, a place to invest and locate progressively sun-set industries and also a bridge to the Middle East for all kind of purposes.

Second, Community's decision makers and member states will have to take into consideration as well Turkey's constant rapprochement to the West, emphasized during the Gulf crisis of 1990-1991. During that period, Turkey chose very bravely to align itself on the international community positions led by the U.S. and the U.K. and to strictly adhere to the decisions of the Security Council of the U.N., even under Iraqi threats. Turkey closed the Iraqi pipelines, deployed its army along its borders with Iraq and even permitted the US Air Force to use Turkish airfields to launch attacks on Iraq. This stand proved Turkey's solidarity with Western-led efforts to overcome naked aggression by a fellow Islamic country ${ }^{3}$. Thus, while in military terms, Turkey's importance to Europe has somewhat diminished as a result of the end of the Cold War, the contrary is the truth in economic and in geopolitic terms. Turkish adherence to the decisions of the U.N. caused economic damage evaluated in billions $\$$. Not surprisingly, then, Turkey expects since 1991 Western Europe's gratitude to materialize in three ways in the coming future. One is compensating for war damages ${ }^{4}$ and another is raising European quotas on a series of restricted exports. However, the most important request to the EC is accepting membership in the future ${ }^{5}$.

Third, Turkish cooperation for achieving stability in the Middle East is very important to the EC. Turkey has proposed to held a conference concerning water problems of the Middle East in Turkey and there is also a Turkish proposal to institutionalize economic cooperation between the countries of the region in order to strengthen any peace settlement there. President Ozal has also declared in the aftermath of the Gulf crisis of 1991 that his country is willing to take part in efforts to solve the Israeli-Arab dispute.

Fourth, the Community seems interested to assist Turkey in maintaining current economic growth in order to stem Turkish migration to the EC, specially at a time when thousands of workers from Eastern Europe and from the Maghreb are moving

3 To be sure, Turkey was not the only Islamic state joining forces against Iraq.

4 The EC has already assisted Turkey with $\$ 250$ million.

5 Turkey cannot easily solicit a write-off or a reduction of its debts the way Egypt did with the U.S. since the majority of its loans were contracted with private banks.

6

Globes (Israel), March 261991. 
to the Community countries because of political instability and/or lack of growth there. The EC fears such a trend and surely must be willing to assist Turkey to back its efforts to develop exports of goods and services rather than exporting workers. In other words, Western Europeans must keep in their minds the risk of Turkey turning to fundamentalism, even if this seems remote nowadays.

Fitth, according to Kramer" since the 1980's Turkey considers itself to be a "Japan" in the region. It has planned since then to establish close economic cooperation both with Middle Eastern countries but also along the shores of the Black Sea with the now-defunct U.S.S.R., Romania and Bulgaria. These plans are in fact materializing after the virtual disintegration of the U.S.S.R. into republics, all but one (i.e. Russia) much smaller than Turkey in economic and demographic terms. On June 25 1992 eleven countries neighbouring the Black Sea have decided, following an invitation by the government of Turkey, to create a Black Sea Community of 400 million people. If the project should lead to the creation of a Common Market, as some predict, that would not be compatible with prior tariff commitments with the EC (i.e. the creation of a customs union by 1995) nor future ones for the matter (i.e. Turkey's membership in the EC). However the final document was quite general and short, allowing meanwhile for some technical cooperation on statistical standardisation ${ }^{8}$. On the other hand the US pushes Turkey to take the lead of the six Muslim republics of the former USSR, stressing the community of culture and language behind. All these new projects may not have any tangible follow-up. About 20 years ago, Turkey tried to develop links with the Islamic world. However the fear of fundamentalism and of what is happening in Algeria, Jordan and Iran is being taken into account by secularists which do not want to go too far in a direction privileged somehow by the Motherland Party, now out of power. Currently there is a big debate in Turkey about which areas are more important to the country in its foreign policy. It seems to me that in the end and given other precedents, Turkey will continue to strive for full integration with Western Europe, which is seen still as the modernizing pole to which Turkey should be attached to. Turkish diplomats hate to see their country as part of the Middle East. They still adhere to the idea that it is better to be "tail of lion" than "head of fox". On the other hand they consider as extremely important that peace reigns in bordering countries such as Syria or Iraq which are clearly part of the Middle East. I remain convinced on the basis of a study of trends in Turkish foreign policy and therefore assume in what follows that the government of Prime Minister Demirel will keep the same path as the previous one dominated by the Motherland Party in strengthening ties with the EC.

Given this, it seems critical to assess now the positive and negative implica-

7 Kramer. H. (1988), Westeuropa und die Turkei: auf dem Weg zum 13. Mitglied der EG?, Ebenhausen, Stiftung Wissenschaft und Politik, p. 391.

B The Economist, June 27 1992; Intemational Herald Tribune, July 131992. 
tions that such integrating steps would have for the Middle East. Assuming an official entry date of Turkey some time around the year 2000 , this would take place at the time European Union in economic and monetary terms as well as in foreign affairs would have already been achieved in all likelihood. Of course, I am assuming that the Maastricht Treaty will be ratified by all member states in a matter of one or two years. By the end of the century steps towards common security and defense policies would have been implemented.

\section{THE EC AFTER THE ENTRY OF TURKEY}

In order to reach an idea of how a Community including Turkey would look like and assess its new profile in the international arena, I have listed in Table 1 figures (1) for the present Community; (2) for a Community of 13 countries, including the 12 present members and Turkey and (3) for a Community of 15 countries, including the 12 present members, Austria, Sweden and Turkey. Columns (4) and (5) relate to the share of Turkey in these last two groups respectively.

\section{TABLE 1}

GDP (\$ Billion)

Population (Mo.)

Area (1000 Sq. M.)

Agr. Area (1000 Sq. M.)
(1)

(2)

4855

325.9

4918

2540
4934

381.2

5699

2820
(3)

5251

397.3

$14.5 \%$

$13.7 \%$

$9.9 \%$

6233

2885
(5)

$1.5 \%$

$14 \%$

$12.5 \%$

$9.7 \%$

SOURCE: OECD Economic Surveys; own calculations.

Clearly Turkey would be considered in both hypothetical cases as one of the large countries of the Community in terms of population, area and agricultural area, although small in terms of GDP. Its weight in EC's institutions would be similar to the one of Spain or slightly less, but certainly higher than the one of Greece, Ireland, Portugal or Denmark. In terms of profile, the EC would be much more "Mediterranean" than at present, much more conscious as well of the environmental hazards both in the Mediterranean and Black Seas. The geographical center of the Community would move south. It would include another ex-colonial power, which like France, Britain or Spain make a pretense of having special responsibilities in different areas of the world. In the case of Turkey that would involve the areas covering the ex-Ottoman Empire, including the Middle East. The EC would also become an even bigger ag- 
ricultural super-power than currently and its profile in military terms would be magnified, in view of Turkey's contribution to the Community in terms of area and population. In fact the weight of the EC in overall NATO forces and in the Atlantic Alliance would greatly increase. On the other hand, the EC's oil dependence on the Middle East would also increase. In fact, the enlarged EC would border for the first time this region. The EC would have a vested interest in investing efforts and resources to keep at bay destabilizing forces in its immediate periphery and would have an incentive to promote actively economic and diplomatic cooperation among Middle Eastern countries and between the latter and the EC itself. Turning now to trade dependence of Middle Eastern countries on the EC, clearly Turkish membership would increase it quite substantially for Iraq, Iran and Gulf countries. Clearly, the attraction of such a Community for Middle Eastern countries would be greatly enhanced as well as the EC's economic, political and strategic influence over the whole area. Thus, Turkey's integration in the European Union would be a stabilizing factor for the whole Middle East.

\section{A PRIORI IMPACT OF INSTITUTIONAL CHANGES AFFECTING FUTURE TURKISH-EC RELATIONS}

I will confine myself for lack of space to the economic and political effects of enlargement to Turkey on five countries of the Middle East with which the EC has had special relations since long time. My method is to "take a picture" of the situation at different relevant points of time and make comparisons.

\section{A. CURRENT EC INSTITUTIONAL LINKS WITH MASHREK COUNTRIES AND ISRAEL}

Economic links between the EC and Mashrek countries (i.e. Egypt, Syria, the Lebanon, and Jordan) are dominated by the cooperation agreements signed between the two parties in 1976 in the context of the Global Mediterranean Policy. These include provisions for the duty -and quota- free access of the Mashrek's industrial exports into the EC but for an important list of sensitive products (including textiles). The economic relations between Israel and the EC are based mainly on the Free Trade Area agreement which was signed in 1975. Bilateral free trade was achieved by 1989 . This agreement includes industrial products (except a large number of processed agricultural products). All the five countries and the EC also agreed on preferential treatment for agricultural products in the EC. In fact, more than half of agricultural exports to the EC benefitted from a reduction of more than $50 \%$ of the CCT. As a result of Spain's entry into the EC and in order to minimize trade diversion away from the five, additional protocols between them and the EC were concluded and ratified by the European Parliament in 1987/88, whereby products listed in an- 
nexes (certain vegetables, fruits and flowers) originating in the five Middle Eastern countries would be subject at any time to the same tariffs as those levied on imports from Spain although this would be, with a few exceptions, only applicable to quantities deemed to represent the average volume of past exports to the EC. Tariffs will be progressively reduced until full removal by January 1 1996. Moreover in the protocols the EC pledged to examine the possibility of lowering minimum entry prices for citrus fruit starting in 1990, the date when Spain began to enjoy all the benefits procured by the CAP to the fruit and vegetable sectors ${ }^{2}$. Since the Gulf crisis, the EC has announced at different occasions its intention to deepen its relations with Israel to bring them to the level of those with EFTA countries and even accept in time Israel's entry in the European Economic Area, all this against participation by the EC in the Middle East Peace talks. Such idea has not been made extensive to any other country of the region for fairly obvious economic reasons.

Politically, the relations between the five countries and the Community are institutionalized by an exchange of ambassadors, yearly meetings of the Cooperation Councils contemplated in the different agreements and in some cases reciprocal visits by parliamentary delegations.

The Community is sensitive to the distress of Palestinians in the territories occupied by Israel since 1967 and supports them with financial and other forms of aid. It also insists on the principle that Palestinian products to the EC should be directly exported to the Community and benefit from the same regime as Israeli exports do.

\section{B. TURKISH - EC INSTITUTIONAL LINKS:}

The relations between Turkey and the EC are based on several agreements which were signed in the 1960's and the 1970's, and on additional understandings between them as of the middle of the 1980's.

The first agreement was an Association agreement which was signed in Ankara in 1963. The purpose of the agreement was to assist Turkey in improving its economy, its level of employment and its standard of living. It was also agreed that for a later stage (the so-called transitory stage) the two contracting parties would establish a customs union between them, coordinate their economic policies and move towards a gradual liberalization in the field of services, movement of workers and the right of establishment. The two parties agreed that upon the completion of all the above, the Community would consider the possibility of a Turkish accession to the EC.

9 Financial and technical cooperation is of lesser importance when compared both to institutionalized trade cooperation and to the ODA Mashrek countries and Israel receive from the US, individual EC members or Gulf countries. The EC has promised to multiply its present efforts by 2.7 in the context of its Renovated Mediterranean Policy for the period 1992-96. 
The agreement procured Turkey with unilateral concessions by the EC benefitting its agricultural exports. (The four main export products-raisins, dried figs, tobacco and nuts- were subjected only to quotas). The Community also loaned 175 million UA, in order to assist Turkey in adapting its market to the one of the Community and to soften the shock of opening partially its domestic market to EC exports. At that time this assistance was in relative terms substantial, taking into account that Turkish exports to the EC were less than $\$ 500$ million.

In 1973 an "additional protocol" signed in 1970 came into force. It was supposed to complete the customs union by 1995 and it also procured Turkey further concessions in exports to the EC, including duty-free export of industrial products (except textiles, steel and certain petroleum products which were subjected only to quotas that were supposed to be abolished after twelve years). Turkey also received further concessions on $\mathrm{EC}$ agricultural imports, so that $90 \%$ of Turkish exports to the $\mathrm{EC}$ would from then on enjoy various levels of concession. In the same year, after the accession of Great Britain, Ireland and Denmark to the EC, the quotas on Turkish exports of textile and petroleum products were raised. Turkey undertook to abolish all tariffs on imports from the Community within 22 years, to adopt the CCT during that period, to liberalize the imports from the Community and to gradually adopt the CAP.

Atter 1974 there was a serious setback in Turkish - EC relations in the wake of the economic slowdown which happened after the oil crisis of 1973 , the Turkish intervention in Cyprus and the military takeover of 1980. Community aid to Turkey was suspended and both Turkey and the EC imposed trade limitations on their bilateral trade for economic (i.e. not political) reasons. As a result, Turkey retaliated and suspended the scaled reduction of its own tariffs. The time schedules agreed upon in the agreements of 1963 and 1973 became irrelevant after $1975^{10}$.

From 1983 on, mutual relations improved. Turkey submitted its formal application to join the EC on April 1987. The application was discussed in the European Parliament, the Commission and the Council of Ministers but Turkey did not receive and encouraging answer. Nevertheless, in February 1990 the Council of Ministers announced the strengthening of the cooperation between the EC and Turkey, upon the recommendation of the Commission, including":

1. The establishment of a customs union by the end of 1995 (in fact as originally scheduled in the 1970 protocol).

2. The promotion of cooperation in the areas of industry, technology, services, transportation, energy, telecommunication and environment.

10 For the five countries under focus, the fact that provisions on the free labor movement between Turkey and the EC were not applied, as scheduled, in December 1986 is of no direct concern.

11 Europe, Documents, No. 1589, December 20 1989. For the record, let me remind here that Turkey and EFTA have signed a FTA agreement. 
3. The renewal of financial cooperation - loans and grants of 600 million ECU, which had to be disbursed much sooner. This was the second financial protocol. If everything had gone according to schedule we could be by now in the fourth proto$\mathrm{col}^{12}$.

4. The promotion of the political cooperation by opening a dialogue between the two parties.

Summing up, the Community grants Turkey at present substantial trade concessions to its exports to Europe. Most industrial exports enjoy duty-free access to the Community's market, although exports of textile, iron, steel and petroleum products are limited by quotas. In addition, almost all agricultural exports to the Community benefit from some kind of preference, although Turkish exports fall under strict CAP rules concerning non-members imports (e.g. variable levies).

On the other hand, EC exports to Turkey are not barrierfee neither. They are limited by quotas, import licenses and also various import taxes (preferential customs duties, housing fund tax), although, compared to the past, the attitude towards imports from the EC and from elsewhere for the matter is much more liberal. Following the decisions of February 1990, Turkey is catching-up, by reducing rapidly tariffs on EC exports.

As a result of all this, it is not astonishing that the shares of the EC-12 in Turkey's exports and imports have reached respectively $53 \%$ and $48 \%$. Note however that Turkey will not be part of the Single Market nor of the European Economic Area both scheduled for next January 11993.

Politically, there is a constant exchange of delegations, day to day contacts of officials of both sides and also meetings of a joint parliamentary committee. Turkey and the Community have the same stand concerning the situation in the Gulf and the Israeli - Arab conflict and both parties share the belief that the Palestinians deserve self-determination.

What about the a priori impact of these current links on the four Mashrek countries and Israel? In fact their trade with the EC is not much affected by Turkish - EC links, specially regarding industrial exports to the EC. The existing agreements allow the five countries to export almost with no limitations, but for the important exception of textiles in the case of Egypt; therefore concessions given by the EC to Turkey do not affect generally speaking the ability of Middle Eastern industrialists to access the Community's market. This does not mean that there is no overlapping of the five

12 There has been some movement in this area fairly recently as a result of the lifting of Greece's veto on EC financial support for cooperative projects between Mediterranean countries including Turkey. 
countries' exports and Turkey's own exports to the EC, but this is part of the normal competitive game. If something, the five countries benefit currently from the fact that Turkish textile and petroleum products' exports to the EC are restricted. On the other hand, all the five countries' exporters are increasingly discriminated in the Turkish market as a result of Turkey's tariff dismantling vis-a-vis the EC and now EFTA. While for the moment the impact may be limited because it takes one to three years for (Community and EFTA) operators to exploit the new opportunities, this may change by 1994-95, even before the completion of the EC-Turkey Customs Union.

In the agricultural domain, Turkey has had an advantage over Israel and the Mashrek countries in exports to the EC, because Turkey's main export products are limited only by quotas, while (reduced) duties on imports from other Mediterranean non members still prevail. As explained above, this will change by 1996. Nevertheless, and more practically, overlap in agricultural exports is limited to a few products (such as grapes, cotton and tomatoes).

In the political realm, present EC - Turkish relations do not have any significant meaning for the Mashrek countries or Israel.

\section{TURKISH-EC LINKS AFTER THE CREATION OF THE CUSTOMS UNION IN 1995:}

The customs union between the EC and Turkey will, no doubt, develop further their mutual trade links. On top of the free trade area between them, Turkey will adopt the CCT, lower its import taxes on EC exports and adjust itself to the Common Commercial Policy applied by the EC on third countries (including the EC's Renovated Mediterranean Policy).

The new situation will open the EC's market to Turkish exports (including textiles, clothing, iron, steel and petroleum products). It is likely that present limitations on agricultural exports from Turkey to the EC will not be entirely abolished at this stage because of sensitivity of some member states. On the Turkish side, the adoption of the acquis communautaire means not only opening its domestic industrial market to EC countries but also to EFTA, ACP and Mediterranean-non member countries, including Mashrek countries and Israel. An important expansion of exports by Eastern Mediterranean countries to Turkey is to be expected (See in Annex what is said on trade and investment creation).

Preference erosion will result in some trade diversion in textiles, clothing, petroleum products, iron and steel products, particularly against Egypt and maybe on clothing against Israel as well (See in Annex what is said on trade and investment diversion). Politically, nothing will change for the region because Turkey will not be part of any institution of the Community or be a member of EPC. 


\section{TURKISH ACCESSION TO THE COMMUNITY (THE TRANSITION PERIOD):}

It is not easy to estimate the probable length of the transition period towards full Turkish integration into the EC. On the other hand, considering the fact that the transition period in the cases of Great Britain, Ireland and Denmark was five years, of Greece seven years and of Spain and Portugal ten years, one may estimate a probable transition period of at least ten years for Turkey and this once entry is approved. But on the other hand, it may be much less, say 5 years, given that by 1996 the starting position will be the one of a Customs Union, a stage much beyond, say, than the Preferential Agreement prevailing between Spain and the EC until 1986, when the former entered the Community.

Note that the official entry date of Turkey into the EC would not substantially change its trade relations with the Community. Under the Customs Union agreement, Turkey already would benefit from free trade with the EC. However it is likely that at entry and during (most of) the transitory period, limitations on Turkish agricultural exports would not (yet) be abolished, for two reasons. First, to avoid as long as possible adjustment by competing Community farmers, especially in Greece as well as in other Southern European countries. Second, to avoid giving an immediate advantage to Turkish products over agricultural exports from third countries which already enjoy Community preferences (such as Maghreb countries, but Israel as well). It is also likely that Turkish workers would not benefit yet from free access to Community labour markets at the entry date.

On the other hand, the accession would be very important for Turkey in some other domains. First, Turkey would become a member with full rights in EC institutions and would take part in the decision-making process of the Community. Since the criteria used to fix the number of delegates per country in each institution are based partly on size of population, the Turkish weight in the institutions would be greater than the Irish, Greek, Danish or Belgian ones or thinking about future members than the Austrian one (See section 2 above). Second, the less developed areas in Turkey would enjoy the Community's aid from EC structural funds (such as the ERDF), and loans from the EIB. Third, Turkey would adopt the CAP. That means that Turkish farmers would get export assistance and guaranteed prices. It also means that Turkey would have to adhere strictly to EC quality and health standards. Fourth, Turkey would become a full partner of all the common policies of the EC (such as fisheries policies).

Turkish membership in the EC would thus have some important economic and political implications for Middle Eastern countries. For instance, a large share of Community's budgetary funds would be directed to Turkey, something which might leave less for external aid. On the other hand, the participation of Turkey in EC in- 
stitutions would heighten the awareness of the EC with respect to links with the Middle East and the Eastern Mediterranean (the former Ottoman empire), a little in the same way as the presence of Spain in the Community has led to better EC relations with Latin America. The EC would include an important member fighting for stability and economic prosperity in the Middle East. Since Mustafa Kemal's times, Turkey's foreign policy has strived for good relations with all the world, Israel included. The doctrine was always to have good relations with the neighbours in particular ${ }^{13}$. Furthermore the idea has been since long that there cannot be peace in Turkey as long as there is no peace in the region. Entry into the EC would strengthen Turkey's hand in its struggle for influence in the Middle East against rivals such as Iran. A Turkish contingent could lead EC or WEU pacifying forces in an area that is well known to Turks since Ottoman times. Of course one should expect countries like Iraq or Iran being against Turkey's membership in the EC, in the same vein as Algeria and Libya were against Spain's entry into the Community more than a decade ago. In passing, the fundamentalists' idea of creating an Islamic Common Market does not make much sense without Turkish participation. Clearly, Turkey's entry in the EC would have a demonstration effect over all the Eastern Mediterranean. It would in some sense tell the countries of the region that all the modernization efforts initiated by Mustafa Kemal and the Young Turks more than half-a-century ago were worthwhile, culminating in the economic and political integration in the EC and therefore had been rewarded by the West. It would be interpreted as a victory of the forces of secularism and of democracy over those of fundamentalism, at a time where the latter are on the rise. It would incite neighbouring countries to modernize, a little like the entry of Spain and Portugal in the Community has strengthened Hassan's efforts in restructuring the Moroccan economy and although more slowly in liberalizing the regime. Finally, because of the respect that non-members have nowadays for the economic and political muscle of the EC, Turkey's membership would have a stabilizing influence on the latter's relations with its neighbours (e.g. Syria), a little in the same way that the entry of Greece in the Community had a stabilizing effect on her conflict with Turkey. Membership could even dissuade Iraq and Iran teaming up against Turkey in some distant future.

\section{E. SITUATION AFTER THE END OF THE TRANSITORY PERIOD ONCE TURKEY IS AN EC MEMBER:}

At that stage, Turkey would have an advantage over Eastern Mediterranean countries exporting their agricultural products to the Community. The latter may ask for compensations (as they did in the case of Spain and Portugal) but it is not clear 
yet whether the EC would accede. However, by the time the transitory period would finish (not sooner than 2000, probably much later) the importance of agricultural exports to the EC in some of these-countries' export baskets would be smaller than currently (e.g. in Jordan, Israel or Syria) and they would anyway have ample time to adjust to the new situation. Turkey would have as well to adjust to EC-92 related directives. This may have some favorable impact on the tourism sector of all the Eastern Mediterranean countries (see Annex). Moreover there could be an unexpected bonanza deriving from Turkey's accession to the CAP. All experts predict that Turkey is scheduled to become the breadbasket of the Middle East by the end of the century as a result of coming into stream large-scale irrigation investments (such as the GAP project). Imagine what even minimal CAP support to Turkish cereal producers would imply for the price of massive food imports made by countries like Egypt or Jordan! Finally, the freedom of movement of Turkish workers in the EC would not displace Eastern Mediterranean migrants whose destination is currently not the EC, but Gulf countries or the US. Mostly affected would be Maghreb citizens, which are not the focus of this paper.

\section{CONCLUSIONS}

The focus of the panel is on the future of European-Middle East relations in the wake of the disintegrating old order exemplified by the Cold War. I have tried to explore this future in the eventuality of an entry of Turkey into the EC.

I have shown in this paper that it is in the interest of Middle Eastern countries that Turkey be a member of the European Community for the following reasons:

a) Economically, and in the long run, trade in goods and in ancillary services between Turkey and the Middle East would expand, as a result of adoption by Turkey of the EC's Mediterranean Policy. This includes a large potential in so-called intra-industry trade which in itself could lead to joint ventures and new investment with a view to exporting to the EC and EFTA countries. The cheap-labor advantage in Turkish exports to the EC would not play the same role as now as a result of free trade in goods and free factor movements between Turkey and the EC. Turkey would become a relatively expensive destination for tourists, which would in turn be attracted by locations in the EC's Southern and Eastern periphery. This would draw investments in the tourism sector compensating manufacturing investment diverted to Turkey. In the short run, however, Egypt may suffer from the destabilizing effects of trade diversion, but the EC could take care of that by offering compensations.

b) Politically, the EC would be more interested than ever in a stable and prosperous Middle East. The Community would have a vested interest in peace and economic stability in the Middle East beyond what is currently the case. Therefore one 
could expect the Eastern Mediterranean to be up-graded in the EC's pyramid of privilege. Furthermore, Turkey's entry into the EC could have a "demonstration effect" over the whole Middle East in that it would incite other countries in the Eastern Mediterranean to proceed with structural political and economic reforms as a necessary condition for their integration into the European Economic Area and maybe at some later stage into the Community itself.

In sum, Turkey's entry into the Community would have a substantial, mostly favorable impact on the economies and political systems of Middle Eastern countries. And third, Turkish influence in Middle East political and economic affairs would be enhanced by its incorporation in the European Community.

\section{BIBLIOGRAPHY:}

\section{Books and articles}

- Aklan O. (1985), The Second Enlargement of the European Communities. Probable Effects on the Members and the New Entrants, European Economic Review, Nr. 28, pp. 279-308.

- Baysan, T. (1984), Some Economic Aspects of Turkey's Acession to the EC: resource shifts, comparative advantage, and Static Gains, Journal of Common Market Studies, Vol. 23, No. 1, September, pp. 15-34.

- Ben-Shahar H., Fishelson G., Hirsch Z., eds. (1989), Economic Cooperation and Middle East Peace, London, Weidenfeld and Nicolson, 1989.

- Burrows, B. (1978), A Community of Thirteen? The Question of Turkish Membership of the EC, Journal of Common Market Studies, Vol. 17, No. 2, December, pp. 143-50.

- Deutsches Orient Institut (1984), Turkey and the European Community-Summary Report, December.

- Gruen, G.E. (1985), Turkey's Relations with Israel and its Arab Neighbours: The Impact of Basic Interests and Changing Circumstances, Middle East Review, Vol. 17, No. 3, pp. 33-43.

- Kramer. H. (1988), Westeuropa und die Turkei: auf dem Weg zum 13. Mitglied der EG?, Ebenhausen, Stiftung Wissenschaft und Politik.

- Landau, J. (1980), Politics, Economics and Religion: Turkey and the European Common Market, Oriente Moderno, Nr. 1-6, pp. 163-71.

- Landau, J. (1992), "Foreign Policies Perspectives if Islamic Circles in Turkey", Anatolica, Vol. 18, pp. 137-9.

- Nonneman, G., ed. (1992), The Middle East and Europe, London, Federal Trust for Education and Research.

- OECD Economic Surveys - Turkey, various years.

- Overseas Business Report (1989), Marketing in Turkey, April. 
- "Ready for Europe? A Survey of Turkey (1988), The Economist, vol. 307, No. 7555, June 18.

- Rustow D. and Penrose, T. (1981), Turkey and the European Community, The Mediterranean Chat lenge IV, Brighton, Sussex European Research Center.

- Tovias, A. (1992), "The EC's Contribution to Peace and Prosperity in the Mediterranean and the Middle East: Some Proposals", Jerusalem Joumal of International Relations, Vol. 14, No. 2, March 1992, pp. 123-32.

- Turkey and the Middle East (1985), Special Issue of The Middle East Review, Spring, Vol. 17, No. 3.

- Turkey in Europe - An Assesment of Turkey's Application to Join the EC. (1990) An Intelligence Digest Special Briefing Paper No. 133 U.K.

- Turkish Industrialists and Businessmen's Association (1988), The Turkish Economy.

- Vaner, S. (1982), La Turquie, la Communaute europeenne elargie et la Mediterranee, in J. Touscoz et autres: La Communaute Economique Europeenne Elargie et la Mediterranee, Quelle Cooperation?, Paris, PUF, pp. 64-94.

\section{Official Publications}

- Agreement Establishing an Association Between the EEC and Turkey, Official Journal of the European Communities L 217, December 291963.

- The Additional Protocol and Financial Protocol, Official Journal of the European Communities L 293, December 291972.

- Commission Communication on Strengthening Relations with Turkey Information 39/90 June 6 1990.

- Commission's Opinion on Turkey's Request for Acession to the Community, Europe Documents, Europe, December 201989. 


\section{ANNEX}

\section{Trade and investment creation}

For Mashrek countries and Israel, Turkey's membership in the EC would imply the addition of a market (until now very closed) with a GNP roughly equivalent to that of Portugal and Greece together, to which they will be able to export at privileged prices (because of their agreements with the EC). Turkey is much closer than any of the other Southern European members of the EC, with which Turkey can be compared in many ways. Distance is a factor facilitating servicing and replacement of spare parts and potentially even more important, intra-industry trade (e.g. trade in components). Bulk products can also enter international trade more easily (e.g. cement, building materials, petrochemicals, fertilizers) as well as highly perishable goods (such as fresh fish). There is much room for optimism for industrial exports which will get duty and quota-free access into the huge Turkish market; not so for agricultural products, since the CAP will apply (e.g. reference prices), although for most products Turkish imports will also be duty free, as a result of application by the EC of new rules on agricultural trade contained in the additional protocol signed between Mediterranean non member countries and the EC upon Spain's and Portugal's accession into the Community. Although GDP per capita is less than a third the one of any OECD country (but for Portugal), the picture changes somewhat if GDP per capita is calculated on a PPP basis, in which case it appears that real income per capita is more than half the one in Greece and Portugal ${ }^{14}$. Moreover Turkey's GDP growth has been the highest in the OECD in the 1980s and this trend could well continue. Membership in the EC could itself stimulate growth in Turkey as it did for Spain and Portugal. The EC would be obliged as well to give a helping hand to Turkey in order to facilitate restructuring where needed. On the other hand, population-wise Turkey is much larger than any of the newest members of the Community or those scheduled to become one soon. In fact the population of Turkey is almost equal to the one of Spain, Portugal and Greece together ${ }^{15}$. Demographic data are particularly relevant for the exporter of mass consumption and primary products (including food). A perusal of bilateral trade statistics shows that exports to Turkey originating in the Eastern Mediterranean are abnormally low nowadays not because Turkey's GNP per capita is low, but because tariffs and NTBs imposed by Turkey on exports are high

14 See OECD Economic Surveys: Turkey 1990-1991, Paris, OECD, 1991 where the Turkish GDP per capita on a PPP basis is for $1988 \$ 4348$, while the one of Portugal and Greece are $\$ 6737$ and $\$ 6786$ respectively. Even more striking is the fact that Turkey's GDP calculated on a PPP basis is two thirds the one of Spain and almost four times the one of Greece.

15 in 1989, almost 55 million, while the other three countries together 59 million. Note as well that the three countries' populations tend to stagnale, which is not the case for Turkey. By 2000 Turkey's population will reach the 72 million mark. 
while there are pretty non-existent on, say, exports to Greece, which is about the same distance than Turkey from Eastern Mediterranean ports and has a GNP which is two thirds the one of Turkey ${ }^{16}$. Using Greece as a yardstick, I calculated that, e.g., Israel could expect annual exports to Turkey to be after the latter adopts the ECIsrael FTA four to five times as large as they were in 1987. Italy is further away from Israel than Turkey and in spite of it, the ratio of Israeli exports to the importer's GNP is about the same, which points again to the existence of a substantial trade potential. 1987 data are not the appropriate benchmark for Spain and Portugal, since they entered only in 1986 to the EC and duty free access for Israeli products to both newcomers is only scheduled for 1993 . Using 1990 data we would find already a tremendous expansion of Israeli exports to Spain and Portugal. Roughly speaking exports to Turkey could expand by 80 to 100 million $\$$ compared to 1987 it free trade was applied by Turkey on Israeli exports.

While it is true that Eastern Mediterranean countries would be competing in the Turkish market on a par with all the 19 members of the European Economic Area as far as tarifts and most NTBs are concerned, they would have clear advantages over most EEA competitors (because of geographical and cultural proximity).

Viewed from Turkey, increasing imports originating in the Eastern Mediterranean would be beneficial, in that most would be trade creation rather than trade diversion, simply because Turkey's average MFN tariff is relatively high at present.

Viewed from the Eastern Mediterranean perspective, exports would expand greatly for different reasons:

First, the MFN tariff applied by Turkey on their industrial exports is at present rather high particularly when compared to the rate applied by the main trade partner, namely the EC, which applies zero-rates. Other OECD countries apply very low tariffs. In some cases, Mashrek countries benefit from GSP treatment (e.g. in Switzerland). In other words, exporters nowadays look elsewhere than at Turkey.

Second, they suffer at present from trade diversion in the Turkish market against them and in favour of EC countries. Since many of their industrial and agricultural exports overlap with those of Greece and Italy, this is particularly damaging nowadays.

Third, industrial (and even some agricultural) Eastern Mediterranean exports

16 Trade between Turkey and Eastern Medilerranean neighbours may also be low because Turkey gives tariff preferences to the EC (and in the future to EFTA countries) which it does not apply to Mashrek countries or Israel. As a matter of fact, the same kind of discrimination is applied by israel against Turkey, which is much affected since Israel has been giving quola -and duty- free access to EC exports since 1989. On top of it, Israel is dismantling its tariff progressively vis-a-vis the US and now EFTA as well. 
would be favored almost across the board, and tend to displace in the Turkish market some NICs whose exports to the latter would be submitted to the CCT and EC NTBs (such as antidumping duties). It is unlikely that Turkey would be obliged by the EC to apply GSP rates to Third World countries' exports at least in the foreseeable future.

One can also envisage semi-manufactured products and components being shifted back-and-forth between Turkey and its Eastern Mediterranean neighbours for further processing with the intention of exporting the product ultimately to EEA markets. In other words, I am speaking about intra-industry trade with a view of selling the end product world-wide. Some parts in the production process would be completed in Turkey, while other parts would be completed in neighbouring countries. That could draw investments particularly in areas neighbouring Turkey such as Northern Syria. Of course this applies a fortiori to neighbouring Black Sea countries as well.

Beyond trade in goods, once wages begin to raise in Turkey (as has happened in Spain upon accession in the EC) one may expect Turkish firms to import labour from poorer countries in the neighbourhood, such as Egypt or Jordan.

\section{Trade and investment diversion}

Turkey and the Eastern Mediterranean do not export by and large the same vegetable and fruits to the EC. Turkey is very strong in dried fruit and tobacco, the latter in fresh fruit and vegetables. There is some overlap for grapes, pulses, tomatoes and of course for cotton. As far as industrial products are concerned, quite problematic would be the case of clothing, leather, iron, steel and petroleum products, given the fact that EC NTBs on Turkish imports are currently very restrictive. Clearly mostly affected by trade diversion would be Egypt. Jordan and Syria on the other hand would only be marginally affected. Trade diversion effects could be amplified by investment diversion in sectors noted above. However this would be compensated by a new investment potential in other sectors (see next section).

\section{Reverse trade diversion}

Tourism flow diversion in favour of Eastern Mediterranean destinations may be anticipated as a result of an EC enlargement to embrace Turkey (as well as Cyprus and Malta) for the following reasons:

- There would a rise in the new entrants' food prices (a real perverse effect) as a result of adoption of the CAP.

- There would be an increased tendency for wage levels to come closer to the 
EC average, once the freedom of movement of workers, capital and goods are established.

As for Spain and Italy, Turkey (as well as Malta and Cyprus) would become a more expensive country for tourism once in the EC. This would favour destinations further afield and promote investment in tourism services in all the Eastern Mediterranean.

The potential for diversion is non negligible given that tourism to Turkey has reached already the 6 -million mark and is continuously growing. 